\title{
Assisting Rural Womens for using Basic Electronic Gadgets for Safety Purposes
}

\author{
Anudevi, V. Sailaja, S. Binapani
}

\begin{abstract}
The Indian Self-Help Group (SHG) movement has been working in the exact direction in recent years to empower women and eradicate poverty in rural and urban areas. Women in India have a strong confidence in the campaign and are responsible for improving their livelihoods. The present study is to evaluate the quality of SHGs chosen for the investigation from the district of Kanchipuram and the district of Chennai. The study's broad goal is to analyze the SHGs operating system for saving mobilization, credit delivery to the needy, repayment of loans, and building SGH members 'opinion on increased decision-making power. All primary and secondary data are obtained and demographic information analyzes age, family structure, and number of dependents in the household. The study emphasizes the role of SHGs for their integration in empowering women, social cohesion, and socio-economic improvement of the poor.
\end{abstract} Power.

Keywords: Poverty, Self Help Group, Decision Making

\section{INTRODUCTION}

\section{A. Self Help Group}

SHG is a small group of rural poor people who have come forward voluntarily to form a social development group and improve the members ' lifestyle. SHG members agree to save and contribute to a mutual fund on a regular basis. Members agree to use this common fund and other funds (such as bank grants and loans), which they may receive as a group, to give small loans to the needy members according to the group's decision[1]-[4].

\section{B. Need of Self Help Group}

Because of various reasons, rural poor are disabled because most of them are socially backward, analphabet, with low motivation and poor economic base. Individually, a poor man is not only disadvantaged in socio-economic terms but also lacks access to the knowledge and information that are the most important components of today's process of development.

\section{Role of Self Help Group}

- Organizing members ' energy and improving the living conditions of the vulnerable.

Revised Manuscript Received on December 11, 2019

Anudevi, Department of Science and Humanities, Bharath Institute of Higher Education and Research, Chennai , India. Email: Anudevi28@gmail.com

V. Sailaja, Department of Science and Humanities, Bharath Institute of Higher Education and Research, Chennai , India. Email: psaillajagmail.com

S. Binapani, Department of Science and Humanities, Bharath Institute of Higher Education and Research, Chennai, India. Email: bina.saravanangmail.com
- Building awareness of protections that help with financial aid.

- To find and solve problems for the team.

- To build teamwork and leadership skills.

\section{REVIEW OF LITERATURE}

Nayak (2007) analyzes the empowerment of the poor in the Kalahandi district of Odisha through SHG and microfinance. The questionnaires have been prepared and submitted to 997 sample 80 SHG members. The study found that 89194 Kalahandi district families benefited from SHGs and bank linkage program and suggested that cooperative sectors be strengthened[5]-[8].

Anitha and Revenkar (2007) studied rural development through micro-credit, SHG growth between 1992-93 and 2003-04, and SHGs related to agency-wise on March 31, 2004. They concluded that SHGs ' success not only enhances the economic status of women, but also has brought many changes to their social status.

\section{DATA COLLECTION AND ANALYSIS}

The work was carried out in the Kanchipuram districts and Chennai districts. Therefore, the list of all the SHGs from the selected blocks of district procured for the investigation. The census method was used to select the SHGs from the selected blocks.

Investigator tried to contact the entire SHGs member however due to some reasons the total number of women members of SHGs contacted from selected districts were 198. Some of the respondents could not be contacted as they were not available at the time of interview[9]-[12]. Observation, focused group discussion and case study method were also used to support the quantitative data. Analysis of the data was done with the help of different statistical tool like frequency distribution, percentage, mean, standard deviation, weighted mean score, correlation coefficient(r) as well as multiple linear regressions.

\section{RESULT AND DISCUSSION}

- Majority of the assenters were of middle age group i.e. 81.81 per cent belonged to the age group of 31 to 46 years.

- The results of the study indicated that 46.96 per cent respondents had primary education followed by Middle school 25.75 per cent.

- The results of the study indicated that 41.91 per cent of the assenters belonged to

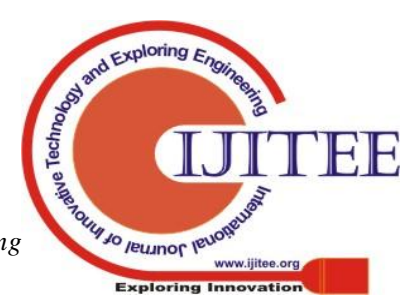




\section{Assisting Rural Womens for using Basic Electronic Gadgets for Safety Purposes}

Scheduled Caste/ Tribe followed by other backward caste 39.39 per cent.

- The results of the study indicated that 45.45 per cent of the respondents belonged to Hindu religion followed by Sikh religion 40.90 per cent.

- More than half of the respondents 57.07 per cent belonged to joint family system followed by 42.92 per cent belonged to nuclear family system.

- More than half of the respondent's 52.52 per cent belonged to large family size followed by medium 36.86 per cent[13]-[18].

- The result of the work shows that the 85.85 per cent respondents were housewives followed by Daily farm labour 14.14 per cent.

- Under the present investigation 75.25 per cent of the population belonged to agricultural background followed by 11.11 per cent had business as an occupation.

- The highest number of women respondents 56.06 per cent were found in the medium income group (Rs. 25,589 to $43,641)$ followed by 41.41 per cent in low income group.

\section{A. Performance of SHGs}

- The result of the work indicate that half of the assenters $(50 \%)$ were found to be always actively work for group constitution followed by 39.39 per cent were sometime work. only 10.10 per cent respondent were observed that they never perform.

- Majority of the respondents 70.70 percent were found to be in the category of always and 19.19 percent SHGs members in sometime. Only 10.10 percent were never in terms of organizational discipline of SHGs. As regards the interest of members in group activities the all SHG members shows that almost all women SHG members have interest in group's activity, which in a way reflects their involvement and participation.

- More than half 52.00 percent of the respondents were always performing in all SHGs activities while 40.40 percent were sometime perform. Only 7.07 percent respondent were observed to be never perform SHGs activities in terms of organizational system[19]-[22].

- The result of the study indicates that 42.92 percent respondents were observed to be having sometime performed the SHGs activities whereas 41.41percent always perform SHGs work. Only 15.65 percent respondents were observed that they never perform SHGs work in terms of financial management.

- The results of the study indicated that the respondents 45.45 percent were found to be always actively worked for external linkage followed by 36.36 per cent were sometime work. Only 18.18 per cent respondents were observed that they never perform any SHGs activity in terms of external linkage.

- Greater part of the assenters i.e. 78.94 percent respondents were observed to be having always performed the SHGs activities and recognized by family member and community where as 24.24 percent sometime perform SHGs work.

\section{B. Change in personal financial position}

- In terms of their impact on the financial status of these women, 79.79 percent of respondents in groups believe that their financial position has changed for the better since they joined the SHG and 18.18 percentage points out that the situation is the same as ever and just 2.02 percentage points out that they can not say anything[23].

- Greater part of the assenters i.e.64.64 percentage in the groups have reported a positive influence on their share in the family income and 23.23 members state that the situation remained the same; only 12.12 percentage members in these categories respectively say that they cannot say anything.

- Among all the respondents, the 48.98 percentage saying that they get to participate in the family's financial decisions and 38.38percent members of the groups reported that they participate as much as before.

\section{RECOMMENDATIONS AND CONCLUSION}

The SHG's fundamental concept is that women need to save and save as a team. Experience had shown that men were poor defaulters, which is why they turned to lending to women. Since the early 1990s, the Indian government has adopted as part of its development strategy the strategy of forming women's groups linked to credit. SHGs are now seen as a way to eradicate poverty and play a role in empowering rural poor women. State governments have also planned various types of schemes to encourage the establishment of SHGs and to provide them with credit so that they can engage in economic activities[24]-[25]. The existing study was to discover out the socio-personal, economic, and psychological characteristics of SHGs members. Based on the study's key findings, it was concluded emergence of women at the grass root level was dominated by educated, middle aged and of reserved categories women with medium economic status. India's financial development depends on both sex workforces' productivity. Women were confined within the four walls of their homes in country like India during the initial period and were dominated by males. Of late, the concept of self-help groups (SHGs) has made incredible progress, and women are now contributing to various activities. The income level of the women looks to be in the growing drift.

\section{REFERENCES}

1) Vasanthi, S. \& Rabiyathul Basariya, S. 2019, "Influence of value analysis and cross training in industry", International Journal of Engineering and Advanced Technology, vol. 8, no. 6, pp. 1810-1811. 
2) Velvizhi, R., Sri Gowtham, S. \& Jeya Priya, D. 2019, "Examination of early feedbacks for effective product retailing on E-commerce websites", International Journal of Engineering and Advanced Technology, vol. 8, no. 6 Special Issue 2, pp. 703-706.

3) Anuradha, C., Pothumani, S. \& Kavitha, R. 2019, "A novel method towards E-commerce", International Journal of Engineering and Advanced Technology, vol. 8, no. 6 Special Issue 2, pp. 535-538.

4) Thomas, J. \& Rabiyathul Basariya, S. 2019, "A study on the issues of financial ratio analysis", Indian Journal of Public Health Research and Development, vol. 10, no. 3, pp. 1079-1081

5) Ramachandran, S. \& Rabiyathul Basariya, S. 2019, "Online marketing study on customer satisfaction and relationship", Indian Journal of Public Health Research and Development, vol. 10, no. 3, pp. 1072-1078.

6) Priya, R., Vinothini, G. \& Cor Jesu, C.D. 2019, "The mentor-protégé relationship for professional growth", Journal of Advanced Research in Dynamical and Control Systems, vol. 11, no. 9 Special Issue, pp. 1110-1119.

7) Jannifer Rani, N., Bina Pani, S. \& Nimisha, N.S. 2019, "A study on money back polices available in LIC", Journal of Advanced Research in Dynamical and Control Systems, vol. 11, no. 9 Special Issue, pp. 833-839.

8) Saillaja, V., Jhansi Rani, K. \& Catherine, R. 2019, "Global marketing management planning and organization", Journal of Advanced Research in Dynamical and Control Systems, vol. 11, no. 9 Special Issue, pp. 489-493.

9) Saillaja, V., Jhansi Rani, K. \& Catherine, R. 2019, "The new phase of marketing information system", Journal of Advanced Research in Dynamical and Control Systems, vol. 11, no. 9 Special Issue, pp. 482-488.

10) Thoufiqulla \& Raju, D.V. 2019, "Perception of indian investor towards investment in mutual funds with special reference to mip funds", Journal of Advanced Research in Dynamical and Control Systems, vol. 11, no. 5, pp. 177-183.

11) Jasmine, K.R.M. \& Basariya, S.R. 2018, "A study on the customers benefits on mutual funds", International Journal of Civil Engineering and Technology, vol. 9, no. 4, pp. 45-48.

12) Vasanthi, S. \& Basariya, S.R. 2019, "Pros and cons of on the job training versus off the job training", International Journal of Scientific and Technology Research, vol. 8, no. 10, pp. 671-674.

13) Pavithra, J. \& Ganesan, M. 2016, "A study on awareness and impact of micro-financial schemes", International Journal of Applied Business and Economic Research, vol. 14, no. 8, pp. 5449-5460.

14) Pavithra, J., Dilli Babu, P. \& Ambuli, T.V. 2014, "A study on budgetary control at Maruti Service Masters, Chennai", International Journal of Applied Business and Economic Research, vol. 12, no. 2, pp. 151-161.

15) Gunaraja, T.M. \& Venkatrama Raju, D. 2018, "Determining factors of organisational climate with reference to leadership styles", International Journal of Mechanical Engineering and Technology, vol. 9, no. 9, pp. 1327-1332.

16) Gunaraja, T.M. \& Venkatrama Raju, D. 2018, "The role of job satisfaction and training of employees in determining organisational climate of a selected industry", International Journal of Civil Engineering and Technology, vol. 9, no. 8, pp. 1266-1269.

17) Aarathy, T.S. \& Raju, D.V. 2018, "Performance appraisal and its effects on employees with respect to it sector in Chennai city", International Journal of Civil Engineering and Technology, vol. 9, no. 6, pp. 1535-1538.

18) Aarathy, T.S. \& Raju, D.V. 2018, "Employee perception towards performance appraisal system in IT sector", International Journal of Mechanical Engineering and Technology, vol. 9, no. 5, pp. 131-135.

19) Porselvi, W., Jublee, D. \& Sivanesan, G. 2018, "A study on factors influencing adoption of technology and innovation in banking industry, tamilnadu, India", International Journal of Mechanical Engineering and Technology, vol. 9, no. 5, pp. 789-800.

20) Akessa, G.M. and Dhufera, A.G., 2015. Factors That Influences Students Academic Performance: A Case of Rift Valley University, Jimma, Ethiopia. Journal of Education and Practice, 6(22), pp.55-63.

21) Miller, G. and Shih, C.C., 1999. A faculty assessment of the academic rigor of on-and off-campus courses in agriculture. Journal of Agricultural Education, 40, pp.57-65.

22) Tsinidou, M., Gerogiannis, V. and Fitsilis, P., 2010. Evaluation of the factors that determine quality in higher education: an empirical study. Quality Assurance in education, 18(3), pp.227-244.

23) Farooq, M.S., Chaudhry, A.H., Shafiq, M. and Berhanu, G., 2011. Factors affecting students' quality of academic performance: a case of secondary school level. Journal of quality and technology management, 7(2), pp.1-14.

24) Fitsilis, P., Gerogiannis, V. and Anthopoulos, L., 2014. Ontologies for software project management: a review. Journal of Software Engineering and Applications, 7(13), p.1096.

25) Adams, J.D. and Jaffe, A.B., 1996. Bounding the effects of R\&D: an investigation using matched establishment-firm data(No. w5544). National bureau of economic research.

\section{AUTHORS PROFILE}

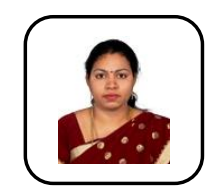

Anudevi Assistant Professor, Department of Science and Humanities, Bharath Institute of Higher Education and Research, Chennai, India.

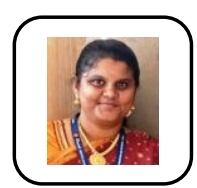

V. Sailaja Assistant Professor, Department of Science and Humanities, Bharath Institute of Higher Education and Research, Chennai, India.

S. Binapani Assistant Professor, Department of Science and Humanities, Bharath Institute of Higher Education and Research, Chennai, India. 